Article

\title{
How Does Sustainable Rural Tourism Cause Rural Community Development?
}

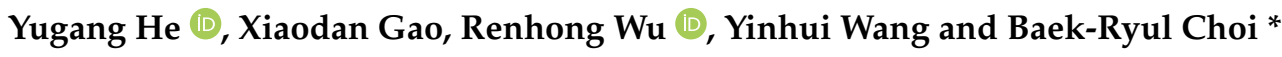 \\ College of Commerce, Jeonbuk National University, Jeonju 54896, Korea; 1293647581@jbnu.ac.kr (Y.H.); \\ gaoxiaodan92@naver.com (X.G.); wurenhongbini@163.com (R.W.); wyh1103@jbnu.ac.kr (Y.W.) \\ * Correspondence: brchoi@jbnu.ac.kr
}

Citation: He, Y.; Gao, X.; Wu, R.; Wang, Y.; Choi, B.-R. How Does Sustainable Rural Tourism Cause Rural Community Development? Sustainability 2021, 13, 13516. https://doi.org/10.3390/ su132413516

Academic Editors: Sergio Moreno-Gil and Arminda Almeida Santana

Received: 3 November 2021

Accepted: 26 November 2021

Published: 7 December 2021

Publisher's Note: MDPI stays neutral with regard to jurisdictional claims in published maps and institutional affiliations.

Copyright: (c) 2021 by the authors. Licensee MDPI, Basel, Switzerland. This article is an open access article distributed under the terms and conditions of the Creative Commons Attribution (CC BY) license (https:// creativecommons.org/licenses/by/ $4.0 /)$.

\begin{abstract}
Rural tourism has been developing vigorously, and rural community functions are becoming diversified in China. Therefore, this paper takes China as an example to explore how sustainable rural tourism affects rural community development in the long and short run over the period 1994-2020. Sustainable rural tourism can be measured using two indicators: total rural tourism revenue and number of rural tourists. Rural community development is measured by the number of rural community service institutions. Then, by incorporating other variables and using the autoregressive distributed lag bounds co-integration technique to perform an empirical analysis, we found that, whether in the long or short run, sustainable rural tourism always plays a positive and significant role in promoting rural community development. In particular, in the long run, rural infrastructure construction, rural ecological environment, agricultural fiscal expenditure, agricultural technological progress, and rural human capital are identified as the major forces behind rural community development. Meanwhile, in the short run, rural infrastructure construction, rural ecological environment, agricultural fiscal expenditure, agricultural technological progress, and rural human capital are also major drivers of rural community development. This paper contributes to the current literature by filling in the existing gaps in several aspects.
\end{abstract}

Keywords: sustainable rural tourism; rural community development; autoregressive distributed lag bounds co-integration technique; long and short run effects

\section{Introduction}

Rural tourism is a new driving force for the sustainable development of the tourism industry [1,2]. As an effective way to implement the Rural Revitalization Strategy-a kind of rural development policy issued by China's central government on 18 October 2017; it gives priority to the development of agricultural and rural areas, and its purpose is to make the countryside a beautiful place for living and working in peace and contentment-it has played a great role in accelerating the agricultural and rural modernization, urban-rural integration, as well as poverty alleviation in poor areas [3]. The rural tourism experience of rural life is aimed at enjoying rural pastoral beauty, engaging in the agricultural planting and breeding industry, rural primitive ecological environment, and folk culture in order to attract the attention of tourists. This makes rural tourism a new multi-modal tourism involving play, relaxation, vacation, creation, shopping, and learning. Rural tourism is a form of tourism with tourism vacation as its purpose and the rural environment as its carrier. At present, it comprises a popular and important direction of tourism development in China. Meanwhile, as a relatively complete regional social community composed of a certain number of people living in rural areas, the role of rural communities in rural development has become increasingly obvious in China [4-6]. Specifically, they can affect the rural culture, rural education, ecological environment, etc. [7-9].

With the rapid development of rural tourism and the significant increase in the role of rural communities in rural development, in recent years, the interest of many scholars 
has been aroused, regarding exploration of the relationships between rural tourism and community development. Guo and Huang [10] have claimed that there is a dual interactive relationship between rural community development and rural tourism. This idea has also been supported by the following studies: Jing-Ming [11] considered that supporting and participating in rural tourism development is one of the basic responsibilities of rural communities. As a part of rural tourism resources, rural community residents are not onlookers of rural tourism activities. Every rural community resident has the right to participate in the development of rural tourism resources. Similarly, Du and $\mathrm{Su}$ [12] and Du and Su [13] have stated that participating in the construction of rural tourism is also the responsibility of rural communities. The active participation of rural communities in rural tourism is conducive to the sustainable and healthy development of rural tourism and the improvement of farmer income levels. Furthermore, Shaohua [14] held the view that sustainable rural tourism development is inseparable from the support of rural community development. Due to the rapid expansion of rural tourism, a large number of outsiders enter rural areas. Guo and Han [15] and Yishan [16] believe that, although rural tourism can promote rural economic development, it also brings a series of problems, such as environmental and ecological problems, conflict between outsiders and locals, and so on. They found that one of the functions of the rural community is as a direct undertaker for solving these problems brought about by rural tourism. To better solve these problems, the function of rural community must be given full play, in order to realize the sustainable development of rural tourism and rural community. In addition, Wang and Hao [17] have pointed out that rural tourism development is inseparable from the extensive participation of rural communities. However, to enable rural communities to participate in the development of rural tourism, the government needs to reasonably support and guide rural community participation. With the promotion of new rural construction in China, Jie [18] and Qiao-Hui [19] found that the relationship between rural tourism and rural community development has become more strong.

In addition to the analysis presented above, a significant number of academics investigate the link between sustainable rural tourism and rural community development from more specific and realistic perspectives in order to provide more innovative findings. Fong and Lo [20] conducted a questionnaire survey to investigate the relationship between community engagement and sustainable rural tourism from the perspective of local communities. They discovered that engagement in decision-making by local communities, empowerment, and community knowledge about tourism all had an impact on the sustainability of rural tourism. Fun et al. [21] investigated the association between local community participation and sustainable rural tourism using a Sarawak sample. They revealed that local community engagement (participation in decision making, information sharing, empowerment, and degree of knowledge about the tourism business) might positively influence sustainable rural tourism (social, cultural, economic, and environmental characteristics) through self-efficacy. This finding was also supported by Fong et al. [22]. Aref and Gill [23] employed qualitative methods to demonstrate sustainable rural tourism through rural cooperatives with a sample of Iran. They came to the conclusion that local community-based tourism might play a critical role in reducing poverty in rural regions. Therefore, rural tourism will be able to thrive in this manner. Conversely, according to the results of empirical study conducted in two distinct inland zones of Portugal, Ribeiro and Marques [24] suggested that a large gap and significant contradictions were emerging between rhetoric and real benefits that tourism has been producing in the local societies and economies of these religions. Subsequently, De Jesus [25] found that the importance of the host community in the development process was frequently overlooked. They examined the outcomes of a research that focuses on locals' views of tourist effects in rural areas in Portugal in order to contribute to sustainable tourism. Although descriptive data suggested some good impressions of tourism, there was little question that tourism helped only a minority of people in the rural areas under study, thus widening the gap between wealthy and poor, which was unfavorable for sustainable rural tourism. Furthermore, In 
the case of Malaysian rural tourism, which consists of a vast number of rural villages, each with distinct and different assets, tourist demand factors clearly play an essential role in generating travels to rural tourism regions. Rural tourism allows travelers to reconnect with nature and local culture, and helps in the economic and social recovery of rural religions, as well as with environmental protection and the propagation of local traditions. As a result, Lo et al. [26] performed a study based on the current tourist business in Bario, analyzing the influence of the tourism industry's economic, environmental, social, and cultural elements on the local populations in Bario. Their finding revealed that sustainable rural tourism has had a major influence on local communities' cultural features.

Thus far, we have found that the previous studies mentioned above were all theoretical analyses. To better explore how sustainable rural tourism affects rural community development, both theoretical and empirical analyses are necessary. When both results are consistent, the conclusion regarding this issue can be more reliable. Therefore, to fill this gap, we take China as an example, in order to explore how sustainable rural tourism affects rural community development in the long and short run over the period 1994-2020. Then, using the autoregressive distributed lag bounds co-integration technique, and incorporating other variables (i.e., rural infrastructure construction, rural ecological environment, agricultural fiscal expenditure, agricultural technology progress, rural human capital, and industrialization) to perform an empirical analysis, our findings suggest that sustainable rural tourism positively and significantly affects rural community development, whether in the long or short run. In addition, our empirical findings also suggest that rural infrastructure construction, rural ecological environment, agricultural fiscal expenditure, agricultural technology progress, and rural human capital positively and significantly affect rural community development. On the contrary, industrialization negatively and significantly influences rural community development.

To this end, the remainder of this paper is structured as follows: Section 2 analyzes the previous literature. Section 3 describes the variables and specifies the model. Section 4 provides both our findings and discussions. Finally, our conclusions are given in Section 5.

\section{Literature Review}

Multiple studies have examined the relationship between rural tourism and community development in multiple aspects, such as different time spans, countries, and approaches. In this section, most of the emphasis is put into analyzing previous studies to develop a theoretical foundation for this paper. In the following, two components are fully addressed using samples from the world and China, regarding the relationship between rural tourism and rural community development.

\subsection{Effect of Rural Tourism on Rural Community Development across the World}

One component is the previous studies that have been carried out throughout the world. Gannon [27] has stated that rural tourism is an important factor promoting rural community development. Moreover, in the case of five communities in Jeju Island, South Korea, Hwang et al. [28] also studied this proposition. They found that sustainable rural tourism positively affects community development. In addition, Hambira et al. [29] took Botswana as a sample to study the effect of rural tourism on community development. Using data collected by means of a household survey to perform an empirical analysis, they found that rural tourism is a positive key tool for community development. Using community participation as a proxy for community development, Idziak et al. [30] reached the conclusion that sustainable rural tourism has a positive effect on community participation. Amir et al. [31] considered Malaysia as a case study to discuss the resilience of rural communities with the assistance of sustainability planning in rural tourism, which includes the role of the local government, community resiliency elements, and the rural sustainable development background. Using methods such as extensive literature reviews and site observation, they found that sustainable rural tourism development can help to improve the resilience of local communities. Subsequently, Dogra and Gupta [32] also 
studied this issue using the same issue. Their findings were consistent with those of Amir et al. [31]. Mair et al. [33] used seven rural communities in Ontario, Canada as an example to study the relationship between rural tourism and rural community power. They found that rural tourism is helpful in facilitating the rural community to use its power to improve the rural development. Huang and Stewart [34] found that, by gathering people with different cultural backgrounds into a community, rural tourism can affect community diversity, community structure, etc. These changes can promote sustainable community development.

Moreover, Wijijayanti et al. [35] employed descriptive and qualitative approaches to explore the influence of rural tourism on the local village community from a local economic development perspective. They believed that rural tourism boosted the position of rural communities. In turn, sustainable rural tourism was inextricably linked to rural community support. Interestingly, Petrzelka et al. [36], for example, examined regional survey data from the Intermountain Western United States to better understand rural tourism attitudes toward community engagement while also studying intra-and inter-gender variations. Men were shown to be more involved in community groups. Male views were more influential in the impact of rural tourism on the development of rural communities. In recent years, socioeconomic discrepancies, particularly between rural and urban regions, have piqued the government of Indonesia's interest, prompting the development of a community-based rural tourism initiative as one attempt to address the issue. As a result, Manaf et al. [37] examined the findings of a case study of effective and sustainable community-based tourism in practice in Nglanggeran Tourism Village, Gunungkidul Regency, Yogyakarta, Indonesia. Their major focus was on how the local community, particularly the young, began collaboration and engagement with associated inter-organizational stakeholders, which had contributed to the program's sustainability. In-depth interviews, observation, and document examination were used to gather data and information. Rural religions were undergoing significant socioeconomic changes, necessitating the transformation and diversification of rural livelihoods. To investigate the link between rural tourism and community engagement, Lenaoa and Saarinen [38] conducted a qualitative research in and around the hamlet of Kalakamati in Botswana's North-East District. They discovered that rural tourism is increasingly being used as a strategy for local development in order to boost community participation's long-term sustainability.

To this end, it can be concluded that most scholars agree with the idea that rural tourism positively influences community development. Of course, this achievement has also been supported by previous studies [39-44], which are not analyzed in this subsection.

\subsection{Effect of Rural Tourism on Rural Community Development in China}

Another component is the previous studies in China. Rural tourism in China is closely related to the economic and social development of rural communities. The original intention of developing rural tourism in many rural areas is to realize its economic function. The previous literature has shown that rural tourism can produce positive effects in adjusting the rural industrial structure, improving the income of farmers, and promoting local transfer of the rural surplus labor force. Generally speaking, rural tourism plays a role in driving the economic and social development of rural areas [45-47]. In detail, Hai-peng [48] believes that the relationship between rural tourism and rural community economic development must be re-understood and recognized from the perspective of agricultural modernization and rural communities, giving full play to the role of optimizing resource allocation. Subsequently, Weng and Peng [49] studied the role of rural tourism in affecting the rural community development. They stated that rural tourism helps rural communities to realize their economic role through large industrial relevance and strong driving to other industries. In addition, Zhang et al. [50] have examined the relationship between suburban rural tourism development and community development. They hold the view that, in the context of the rapid development of urban-rural integration, it is very important to take "people-oriented" as the core concept to reshape the regional 
function of rural tourism scenic spots and communities integrating urban and rural areas. This is conducive to the sustainable development of rural tourism and rural communities. Meanwhile, Guo and Huang [10] have discussed the relationship between community culture and the development of modern rural tourism. They found that community culture is an effective allocation resource in the existence and development of rural tourism.

Rural tourism is a significant step forward in the accomplishment of ethnic rural rejuvenation. Using the Shiyi Qiang Stockaded hamlet in Beichuan Qiang Autonomous county of Sichuan province as a sample, Wang et al. [51] investigated the relationship between rural tourism and rural communities using the notion of community empowerment. They revealed that rural tourism could improve community cohesiveness. Yan et al. [52] argued that community involvement in rural tourism was not only an essential type of farmer's participation in tourism and commercial growth, but also an effective strategy to establish a new socialist countryside. Their findings indicated that rural tourism might help to strengthen rural community civilization and capability. Meanwhile, rural tourism has developed as a new force in recent years, serving as a highlight of rural economic growth and an essential method of addressing the issue of local citizens' employment. Using Jiangxinzhou as the study object, they studied the influence of rural tourism on community people' employment. They found that rural tourism could promote the employment of community residents. Lin et al. [53] used survey data from five rural tourism villages in the Ningde World Geopark to perform an empirical study. They believed that rural tourism contributed to the well-being of the community's rural residents. Xian-feng and Jian [54] used the ancient city village of Ningxia a sample to study the effect of rural tourism on Hui community. They found that rural tourism had an influence on Hui community residents' food patterns, kinship, and female status.

To this end, using a sample of China, a large number of scholars believe that rural tourism positively improves community development. This finding has been supported by previous studies [55-61], which are not analyzed in this subsection. In the present state-of-the-art, it can be found that previous studies considering the effect of rural tourism on rural community development are limited. Judging from our current knowledge, the empirical literature is silent towards the assessment of this topic. Thus, this paper attempts to fill this gap by using the econometric technique (autoregressive distributed lag bounds co-integration technique), in order to investigate how sustainable rural tourism affects rural community development. Once again, expanding previous studies in terms of time span, research objects, and rigorous econometric techniques, this paper plans to make up for the deficiencies found in the previous literature.

\section{Variable Description and Model Specification}

This section is divided into three subsections: variable description, model specification, and an explanation of the estimation tools used. In the following, these factors are described in detail.

\subsection{Variable Description}

The International Council on Monuments and Sites has stated that sustainable tourism refers to a level of tourism activity that can be maintained over the long-term, which results in a net benefit for the social, economic, natural, and cultural environments of the area in which it takes place. Based on this statement, Ivars-Baidal et al. [62] and Lee et al. [63] used the economic benefits brought by tourism and the number of local tourists as two important indicators to measure sustainable tourism. As an analogy, in this paper, we use the economic benefits brought by rural tourism to rural areas and the number of rural tourists as two indicators to measure rural sustainable tourism. This treatment is also consistent with previous studies in the literature [64-68].

As for community development, the United Nations defines it as a process where community members come together to take collective action and generate solutions to common problems. It is a broad concept, applied to the practices of civic leaders, ac- 
tivists, involved citizens, and professionals to improve various aspects of communities, typically aimed at building stronger and more resilient local communities. There are numerous indicators to measure the community development due to outcomes or objectives. They include community engagement, community capacity building, community organizing, asset-based community development, and so on. Following Rahman et al. [69], Roba Gamo et al. [70], and Dova et al. [71], we use rural community service institutions to measure community development.

In addition, referring to the previous relevant literature, some other important variables are also added in this paper. Following Ko et al. [72], Sharp et al. [73], and Li et al. [74], rural infrastructure construction is also added into this paper. It is measured through the mileage of rural roads, rural power consumption, the average number of mobile phones per 100 households of rural households, and the number of village clinics. Based on these four indicators, the comprehensive index of rural infrastructure construction is obtained by fitting and calculating with the entropy method to measure the level of rural infrastructure construction. Following Liu et al. [75], Xie et al. [76], and Zhang and Li [77], the rural ecological environment is added into this paper. It is measured in terms of pesticide use, chemical fertilizer application, rural water improvement benefit rate, sanitation toilet penetration rate, rural biogas digester gas production, and rural solar water heaters. Based on these six indicators, the comprehensive rural ecological environment index is obtained by fitting and calculating with the entropy method to measure the level of rural ecological environment. Following Zeng et al. [78], Chen et al. [79], and Zeng et al. [80], the agricultural fiscal expenditure is added into this paper. It is measured as the proportion of agricultural fiscal expenditure to the total local fiscal expenditure. Following He et al. [81], Liu et al. [82], and $\mathrm{Xu}$ et al. [83], agricultural technological progress is added in this paper, which is measured using the total power of agricultural machinery. Following Razzaq et al. [84], Su et al. [85], and Kimbu et al. [86], rural human capital is added into this paper, which is measured as the proportion of the labor force with various rural education to the total rural labor force. Following Long et al. [87] and Jiang et al. [88], industrialization is also added into this paper. It is measured by the proportion of output value of secondary industry to GDP. To understand these variables more intuitively, they will be presented in Table 1.

Table 1. Variable description.

\begin{tabular}{|c|c|c|}
\hline Variable & Form & Definition \\
\hline \multicolumn{3}{|c|}{ Sustainable Rural Tourism } \\
\hline Economic benefits of rural tourism & 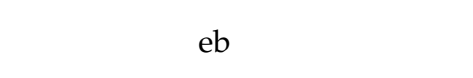 & $\begin{array}{l}\text { Total rural tourism revenue in log (unit: } \\
\text { billion yuan) }\end{array}$ \\
\hline Number of rural tourists & $\mathrm{rt}$ & $\begin{array}{l}\text { Number of rural tourists in log (unit: } \\
\text { million people) }\end{array}$ \\
\hline \multicolumn{3}{|c|}{ Rural Community Development } \\
\hline Rural community service institutions & CS & $\begin{array}{l}\text { Number of rural community service } \\
\text { institutions in log (unit: million) }\end{array}$ \\
\hline \multicolumn{3}{|c|}{ Other Variable } \\
\hline Rural infrastructure construction & ri & $\begin{array}{l}\text { Comprehensive index of rural } \\
\text { infrastructure construction (in log) }\end{array}$ \\
\hline Rural ecological environment & re & $\begin{array}{c}\text { Comprehensive index of rural ecological } \\
\text { environment (in log) }\end{array}$ \\
\hline Agricultural fiscal expenditure & af & $\begin{array}{l}\text { Proportion of agricultural fiscal } \\
\text { expenditure to the total local } \\
\text { fiscal expenditure }\end{array}$ \\
\hline Agricultural technology progress & at & $\begin{array}{l}\text { Total power of agricultural machinery in } \\
\log \text { (unit: hundred million kilowatts) }\end{array}$ \\
\hline Rural human capital & rh & $\begin{array}{l}\text { Proportion of labor force with various rural } \\
\text { education to the total rural labor force }\end{array}$ \\
\hline Industrialization & in & $\begin{array}{c}\text { Proportion of output value of secondary } \\
\text { industry to GDP }\end{array}$ \\
\hline
\end{tabular}

Note: all the data used in this paper are sourced from the National Bureau of Statistics, Rural Tourism Big Data Report, and Rural Tourism Statistics. 


\subsection{Model Specification}

Dangi and Petrick [89] has found that rural tourism is a most important factor in rural community development. Likewise, this paper follows their studies. An approach to particularly explore the effect of sustainable rural tourism on community development in China was established.

As a result, the description used in this paper to examine the effect of sustainable rural tourism on community development is defined as follows:

$$
\mathrm{rs}_{\mathrm{t}}=\mathrm{a}_{1}+\mathrm{a}_{2} \mathrm{cs}_{\mathrm{t}}+\mathrm{a}_{3} \mathrm{ri}_{\mathrm{t}}+\mathrm{a}_{4} \mathrm{re}_{\mathrm{t}}+\mathrm{a}_{5} \mathrm{af}_{\mathrm{t}}+\mathrm{a}_{6} \mathrm{at}_{\mathrm{t}}+\mathrm{a}_{7} \mathrm{rh}_{\mathrm{t}}+\mathrm{a}_{8} \mathrm{in}_{\mathrm{t}}+\epsilon_{\mathrm{t}}
$$

where rs denotes sustainable rural tourism, which includes the total rural tourism revenue and the number of rural tourists; cs stands for the rural community development; ri stands for the rural infrastructure construction; re stands for the rural ecological environment; af stands for the agricultural fiscal expenditure; at stands for the agricultural technology progress; rh stands for the rural human capital; in stands for industrialization; $t$ stands for the year; $a_{1}$ stands for the constant; $\left[a_{2}, a_{8}\right]$ stand for the coefficients to be estimated; and $\epsilon_{\mathrm{t}}$ stands for white noise. In addition, the selection of these variables is generally wellversed, due to the relevance of the feature to China's rural tourism and rural community development, as well as the availability of data during this study.

\subsection{Explanation of Estimation Tools}

Pesaran et al. [90] initially developed the autoregressive distributed lag bounds cointegration technique. Subsequently, they introduced a modification to this technique, which has been extensively used in numerous previous studies [91-94]. Therefore, following the treatment of Rehman et al. [95] and Udemba and Yalçıntaş [96], this paper also uses the autoregressive distributed lag bounds co-integration technique to analyze the effect of sustainable rural tourism on community development. In fact, one advantage is that this technique is quite useful to evaluate the existence of long run economic time-series.

When the variables are $\mathrm{I}(0), \mathrm{I}(1)$, or a combination of both, the autoregressive distributed lag bounds co-integration technique enables the co-integration test. To the contrary, the Johansen approach needs all variables which are I(1). Stated differently, the variables at the first difference are stationary $[97,98]$. Furthermore, the autoregressive distributed lag model can be used even though the sample size is smaller. Meanwhile, the autoregressive distributed lag bounds co-integration technique is considered to provide unbiased long run evaluation, in which there are few endogenous variables. Bound testing often offers unbiased long run measurements and reliable t-statistics, even though there are some explanatory variables which are endogenous [99-101]. However, this technique is considered to be inefficient when the variables at the second difference are stationary. In consideration of the characteristics of the autoregressive distributed lag bounds co-integration technique analyzed above, and following previous studies [102-105], we employ this technique to explore the effect of sustainable rural tourism on community development.

As for the variables in Equation (1), the unit root test is used to investigate their stationary properties. Two kinds of unit root tests include the Phillip-Perron unit root test and the Augmented Dickey-Fuller test to test variables, both in level and in first difference. Then, we test the long run relationship between sustainable rural tourism, community development, and other variables within a univariate framework. The model is mathematically specified as follows:

$$
\begin{gathered}
\Delta \mathrm{rs}_{\mathrm{t}}=\mathrm{a}_{1}+\sum_{\mathrm{i}=2}^{\mathrm{n}} \mathrm{b}_{\mathrm{i}} \Delta \mathrm{rs}_{\mathrm{t}-\mathrm{i}}+\sum_{\mathrm{i}=2}^{\mathrm{n}} \mathrm{c}_{\mathrm{i}} \Delta \mathrm{cs}_{\mathrm{t}-\mathrm{i}}+ \\
\sum_{\mathrm{i}=2}^{\mathrm{n}} \mathrm{d}_{\mathrm{i}} \Delta \mathrm{ri}_{\mathrm{t}-\mathrm{i}}+\sum_{\mathrm{i}=2}^{\mathrm{n}} \mathrm{e}_{\mathrm{i}} \Delta \mathrm{re}_{\mathrm{t}-\mathrm{i}}+\sum_{\mathrm{i}=2}^{\mathrm{n}} \mathrm{f}_{\mathrm{i}} \Delta \mathrm{af}_{\mathrm{t}-\mathrm{i}}+\sum_{\mathrm{i}=2}^{\mathrm{n}} \mathrm{g}_{\mathrm{i}} \Delta \mathrm{at}_{\mathrm{t}-\mathrm{i}}+\sum_{\mathrm{i}=2}^{\mathrm{n}} \mathrm{g}_{\mathrm{i}} \Delta \mathrm{rh}_{\mathrm{t}-\mathrm{i}}+\sum_{\mathrm{i}=2}^{\mathrm{n}} \mathrm{h}_{\mathrm{i}} \Delta \mathrm{in}_{\mathrm{t}-\mathrm{i}}+\lambda_{1} \mathrm{rs}_{\mathrm{t}-1}+ \\
\lambda_{2} \mathrm{cs}_{\mathrm{t}-1}+\lambda_{3} \mathrm{ri}_{\mathrm{t}-1}+\lambda_{4} \mathrm{re}_{\mathrm{t}-1}+\lambda_{5} \mathrm{af}_{\mathrm{t}-1}+\lambda_{6} \mathrm{at}_{\mathrm{t}-1}+\lambda_{7} \mathrm{rh}_{\mathrm{t}-1}+\lambda_{8} \mathrm{in}_{\mathrm{t}-1}+\epsilon_{\mathrm{t}}
\end{gathered}
$$


The bounds co-integration test involves calculating Equation (2) and confining the factors of lag-level variables equal to zero. Therefore, we verify the hypothesis from Equation (2), which is shown as follows:

Null hypothesis:

$$
\delta_{1}=\delta_{2}=\delta_{3}=\delta_{4}=\delta_{5}=\delta_{6}=\delta_{7}=0
$$

Alternative hypothesis:

$$
\delta_{1} \neq \delta_{2} \neq \delta_{3} \neq \delta_{4} \neq \delta_{5} \neq \delta_{6} \neq \delta_{7}=0
$$

The corresponding measured F-statistic is compared with the two asymptotic critical limits of Shin et al. [106], in order to confirm the existence of co-integration. Finally, the error correction model is evaluated as follows:

$$
\begin{gathered}
\Delta \mathrm{rs}_{\mathrm{t}}=\mathrm{a}_{1}+\sum_{\mathrm{i}=2}^{\mathrm{n}} \mathrm{b}_{\mathrm{i}} \Delta \mathrm{rs}_{\mathrm{t}-\mathrm{i}}+\sum_{\mathrm{i}=2}^{\mathrm{n}} \mathrm{c}_{\mathrm{i}} \Delta \mathrm{cs}_{\mathrm{t}-\mathrm{i}}+ \\
\sum_{\mathrm{i}=2}^{\mathrm{n}} \mathrm{d}_{\mathrm{i}} \Delta \mathrm{ri}_{\mathrm{t}-\mathrm{i}}+\sum_{\mathrm{i}=2}^{\mathrm{n}} \mathrm{e}_{\mathrm{i}} \Delta \mathrm{re}_{\mathrm{t}-\mathrm{i}}+\sum_{\mathrm{i}=2}^{\mathrm{n}} \mathrm{f}_{\mathrm{i}} \Delta \mathrm{af}_{\mathrm{t}-\mathrm{i}}+\sum_{\mathrm{i}=2}^{\mathrm{n}} \mathrm{g}_{\mathrm{i}} \Delta \mathrm{at}_{\mathrm{t}-\mathrm{i}}+\sum_{\mathrm{i}=2}^{\mathrm{n}} \mathrm{g}_{\mathrm{i}} \Delta \mathrm{rh}_{\mathrm{t}-\mathrm{i}}+\sum_{\mathrm{i}=2}^{\mathrm{n}} \mathrm{h}_{\mathrm{i}} \Delta \mathrm{in}_{\mathrm{t}-\mathrm{i}}+\lambda_{1} \mathrm{ecm}_{\mathrm{t}-1}+\epsilon_{\mathrm{t}} .
\end{gathered}
$$

Even though the autoregressive distributed lag bounds co-integration technique does not need the unit root test in advance, we believe that the unit root test should be carried out to understand the number of unit roots in the considered time-series, in order to avoid the collapse of the autoregressive distributed lag model in the presence of the comprehensive random trend of I(2) [107-109]. To this end, we use the Augmented Dickey-Fuller and Phillips-Perron unit root tests. The augmented Dickey-Fuller test model is shown as follows:

$$
\begin{gathered}
\Delta \mathrm{y}_{\mathrm{t}}=\mathrm{a}+\mathrm{bt}+\gamma \mathrm{y}_{\mathrm{t}-1}+\sum_{\mathrm{i}=1}^{\mathrm{n}} \beta \Delta \mathrm{y}_{\mathrm{t}-1}+\epsilon_{\mathrm{t}} \\
\Delta \mathrm{y}_{\mathrm{t}}=\mathrm{a}+\gamma \mathrm{y}_{\mathrm{t}-1}+\sum_{\mathrm{i}=1}^{\mathrm{n}} \beta \Delta \mathrm{y}_{\mathrm{t}-1}+\epsilon_{\mathrm{t}}
\end{gathered}
$$

where $\Delta$ stands for the first difference operator; $y$ stands for the time-series; $t$ stands for the linear time trend; a stands for the constant; $\mathrm{n}$ stands for the number of lags, and $\epsilon_{\mathrm{t}}$ stands for the error term. Equation (4) contains the drift and time trends, and Equation (5) contains the drift.

To summarize, based on the above analyses, an empirical analysis regarding the effect of sustainable rural tourism on community development was conducted. According to the empirical results, the corresponding discussion is provided in the following section.

\section{Empirical Results and Discussion}

This section concentrates on the description of basic characteristics of variables, unit root test, bounds co-integration test, long run effect, and short run effect. In the following, we analyze these one by one.

\subsection{Basic Characteristics of Variables}

This subsection describes the mean, maximum, minimum, standard error, and correlations between the variables used in this paper, as presented in Table 2.

Table 2 describes the basic characteristics of the used variables. It can be concluded that the economic benefits of rural tourism have a mean equal to 2.300 with a standard error equal to 0.457 , and the number of rural tourists has a mean equal to 2.866 with a standard error equal to 0.284 . These results indicate that China's rural tourism is gradually booming, but fluctuates greatly. These results are also in line with China's actual situation; that is, the government has been issuing many policies to develop the rural tourism economy. The number of rural community service institutions had a mean equal to 0.233 with a standard error equal to 0.049 . This suggests that China's rural community development is growing steadily and continuously. Moreover, this is also in line with China's new rural 
construction and the government's sustained investments in rural areas to help farmers increase their income. The rural infrastructure construction had a mean equal to -0.441 with a standard error equal to 0.413 , the rural ecological environment had a mean equal to -0.844 with a standard error equal to 0.306 , the agricultural fiscal expenditure had a mean equal to 0.437 with a standard error equal to 0.624 , the agricultural technology progress had a mean equal to 0.851 with a standard error equal to 0.288 , the rural human capital had a mean equal to 0.577 with a standard error equal to 0.357 , and industrialization had a mean equal to 0.445 with a standard error equal to 0.071 .

Table 2. Description of basic characteristics of variables.

\begin{tabular}{|c|c|c|c|c|c|c|c|c|c|}
\hline $\begin{array}{c}\text { Statistics and } \\
\text { Variables }\end{array}$ & eb & rt & cs & ri & re & af & at & rh & in \\
\hline Mean & 2.300 & 2.866 & 0.233 & -0.441 & -0.844 & 0.437 & 0.851 & 0.577 & 0.445 \\
\hline Maximum & 2.989 & 3.186 & 0.528 & -0.377 & -0.743 & 0.545 & 1.048 & 0.723 & 0.476 \\
\hline Minimum & 1.244 & 2.504 & 0.099 & -0.476 & -1.073 & 0.336 & 0.529 & 0.384 & 0.378 \\
\hline Standard error & 0.457 & 0.284 & 0.049 & 0.413 & 0.306 & 0.624 & 0.288 & 0.357 & 0.071 \\
\hline \multicolumn{10}{|c|}{ Correlation Test } \\
\hline Variable & $\mathrm{eb}$ & $\mathrm{rt}$ & CS & ri & re & af & at & rh & in \\
\hline $\mathrm{eb}$ & $\begin{array}{l}1.000 \\
(---)\end{array}$ & & & & & & & & \\
\hline $\mathrm{rt}$ & & $\begin{array}{c}1.000 \\
(----)\end{array}$ & & & & & & & \\
\hline CS & $\begin{array}{l}0.717^{* * *} \\
(5.143)\end{array}$ & $\begin{array}{c}0.629^{* * *} \\
(4.047)\end{array}$ & $\begin{array}{l}1.000 \\
(---)\end{array}$ & & & & & & \\
\hline ri & $\begin{array}{c}0.384 \\
(1.136)\end{array}$ & $\begin{array}{c}0.194^{* * * *} \\
(8.500)\end{array}$ & $\begin{array}{c}0.205^{* * *} \\
(8.139)\end{array}$ & $\begin{array}{c}1.000 \\
(---)\end{array}$ & & & & & \\
\hline re & $\begin{array}{c}0.275 \\
(1.241)\end{array}$ & $\begin{array}{c}0.158 \\
(1.017)\end{array}$ & $\begin{array}{l}0.452 * * \\
(2.533)\end{array}$ & $\begin{array}{c}0.560 * * * \\
(4.594)\end{array}$ & $\begin{array}{c}1.000 \\
(---)\end{array}$ & & & & \\
\hline af & $\begin{array}{l}-0.345^{* * * *} \\
(-3.130)\end{array}$ & $\begin{array}{c}-0.148 \\
(-1.132)\end{array}$ & $\begin{array}{l}-0.095^{* * *} \\
(-6.895)\end{array}$ & $\begin{array}{c}-0.141 \\
(-1.397)\end{array}$ & $\begin{array}{l}-0.117 * \\
(-1.695)\end{array}$ & $\begin{array}{c}1.000 \\
(---)\end{array}$ & & & \\
\hline at & $\begin{array}{l}0.229 * * \\
(2.027)\end{array}$ & $\begin{array}{c}0.401 \\
(1.431)\end{array}$ & $\begin{array}{c}0.472^{* * *} \\
(4.245)\end{array}$ & $\begin{array}{c}0.409 \\
(0.858)\end{array}$ & $\begin{array}{c}0.399 \\
(1.372)\end{array}$ & $\begin{array}{c}-0.327 \\
(-1.293)\end{array}$ & $\begin{array}{l}1.000 \\
(---)\end{array}$ & & \\
\hline rh & $\begin{array}{l}-0.348^{* * * *} \\
(-3.170)\end{array}$ & $\begin{array}{l}-0.106^{* * *} \\
(-11.014)\end{array}$ & $\begin{array}{l}-0.459 * * * \\
(-7.933)\end{array}$ & $\begin{array}{l}-0.267 \\
(-1.665)\end{array}$ & $\begin{array}{l}-0.289^{* * * *} \\
(-6.439)\end{array}$ & $\begin{array}{l}0.171 * \\
(1.613)\end{array}$ & $\begin{array}{l}-0.276 \\
(-1.242)\end{array}$ & $\begin{array}{c}1.000 \\
(----)\end{array}$ & \\
\hline in & $\begin{array}{l}-0.496^{* * * *} \\
(-4.273)\end{array}$ & $\begin{array}{l}-0.552 * * * * \\
(-3.308)\end{array}$ & $\begin{array}{l}-0.490 \\
(-1.912)\end{array}$ & $\begin{array}{l}-0.289^{* *} \\
(-2.291)\end{array}$ & $\begin{array}{l}-0.384^{* *} \\
(-2.079)\end{array}$ & $\begin{array}{c}0.392 \\
(1.488)\end{array}$ & $\begin{array}{l}-0.491 \\
(-1.351)\end{array}$ & $\begin{array}{c}0.105^{* * *} \\
(6.691)\end{array}$ & $\begin{array}{l}1.000 \\
(---)\end{array}$ \\
\hline
\end{tabular}

Note: * $10 \%$ significance level; ${ }^{* *} 5 \%$ significance level; ${ }^{* * *} 1 \%$ significance level; T-statistics shown in parentheses.

In addition, the results of the correlation test indicated that the correlation between community development and economic benefits of rural tourism was positive. This indicates that the economic benefits of rural tourism play a promoting role in community development. Furthermore, it was also found that the correlation between the number of rural tourists and community development was positive. This also proves that the number of rural tourists can promote community development. Based on previous studies $[110,111]$, it can be concluded that there was no significant correlation between these variables. In summary, we can preliminarily judge that sustainable rural tourism is positively correlated with community development.

\subsection{Unit Root Test}

To prevent virtual regression, the stationarity of all variables used should be ensured before the regression analysis [112-115]. Therefore, in this paper, both the Augmented Dickey-Fuller and Phillips-Perron unit root tests were conducted to examine the stationarity of each variable [116-119]. The results are presented in Table 3. 
Table 3. Results of unit root test.

\begin{tabular}{|c|c|c|c|c|}
\hline \multirow{2}{*}{ Variable } & \multicolumn{2}{|c|}{ Augmented Dickey-Fuller Test } & \multicolumn{2}{|c|}{ Phillips-Perron Test } \\
\hline & Level & 1st Difference & Level & 1st Difference \\
\hline $\mathrm{eb}$ & -0.929 & $-4.781 * * *$ & -1.047 & $-4.741 * * *$ \\
\hline $\mathrm{rt}$ & -0.424 & $-4.337^{* *}$ & -0.424 & $-4.197^{* *}$ \\
\hline Cs & -0.464 & $-3.676^{* *}$ & -0.688 & $-3.644^{* *}$ \\
\hline ri & $-3.277^{*}$ & $-4.319^{* *}$ & -2.492 & $-4.179 * *$ \\
\hline re & 3.644 & $-4.454^{* *}$ & -0.213 & $-6.237^{* * *}$ \\
\hline af & -2.689 & $-5.411^{* *}$ & -1.839 & $-5.509 * * *$ \\
\hline at & -0.208 & $-4.549 * *$ & -0.208 & $-4.547^{* *}$ \\
\hline rh & $-4.273 *$ & $-4.752 * *$ & $-3.549 *$ & $-5.175^{* *}$ \\
\hline in & -0.612 & $-3.573 * *$ & -0.805 & $-3.547^{* *}$ \\
\hline
\end{tabular}

Note: ${ }^{*} 10 \%$ significance level; ${ }^{* *} 5 \%$ significance level; ${ }^{* * *} 1 \%$ significance level.

As the results in Table 3 indicate, both the independent variable and dependent variable were I(1) at the $1 \%$ or $5 \%$ significance level. As a result, the bounds co-integration test was employed to determine whether there was a long run relationship among the variables used in this paper [120]. In the following, we detail the bounds co-integration test.

\subsection{Bounds Co-Integration Test}

This subsection focuses on the bounds co-integration test. As two indicators of rural tourism were used to measure sustainable rural tourism, we used two groups with different indicators to conduct the bounds co-integration test. The results are presented in Table 4 .

Table 4. Results of bounds co-integration test.

\begin{tabular}{|c|c|c|c|c|c|c|c|c|c|}
\hline $\begin{array}{c}\text { Test } \\
\text { Statistic }\end{array}$ & Value & $\begin{array}{l}\text { Significant } \\
\text { Level }\end{array}$ & $\mathbf{I}(0)$ & $\mathbf{I}(1)$ & $\begin{array}{c}\text { Test } \\
\text { Statistic }\end{array}$ & Value & $\begin{array}{l}\text { Significant } \\
\text { Level }\end{array}$ & $\mathrm{I}(0)$ & I(1) \\
\hline F-Statistic & 5.424 & & & & F-Statistic & 4.038 & & & \\
\hline & & $10 \%$ & 1.92 & 2.89 & & & $10 \%$ & 1.92 & 2.89 \\
\hline & & $5 \%$ & 2.17 & 3.21 & & & $5 \%$ & 2.17 & 3.21 \\
\hline & & $1 \%$ & 2.73 & 3.90 & & & $1 \%$ & 2.73 & 3.90 \\
\hline \multicolumn{5}{|c|}{ Group 1: Economic benefits of rural tourism } & \multicolumn{5}{|c|}{ Group 2: Number of rural tourists } \\
\hline
\end{tabular}

Table 4 shows the results of the bounds co-integration test. It can be obviously found that the respective calculated value of F-statistic is greater than that of the upper bound critical value for the normalized equation. In detail, for group 1, the F-statistic is equal to 5.424 and significant at the $1 \%$ level. For group 2, the F-statistic was equal to 4.038 and significant at the $1 \%$ level. Therefore, we can conclude that the null hypothesis of no cointegration was rejected. As a result, it can be confirmed that there was long run co-integration between the variables used in this paper.

\subsection{Long Run Effect of Sustainable Rural Tourism on Rural Community Development}

This subsection focuses on the long run effect of sustainable rural tourism on rural community development. Driven by the assumption that the model in this paper has rural community development as the predicted variable, we attempted to estimate the long run rural community development of China. To conduct the empirical analysis, the maximum lag length was set to 4 . Based on the Akaike information criterion, the selected model for economic benefits of rural tourism was autoregressive distributed lag $(2,1,2,2,2,2,2)$, and the selected model for number of rural tourists was autoregressive distributed lag $(2,2,2$, $2,2,1,2)$. The results are presented in Table 5 . 
Table 5. Long run effect results.

\begin{tabular}{ccc}
\hline Variable & cs & cs \\
\hline eb & $0.049^{* * *}$ & \\
& $(8.446)$ & $0.134^{* * *}$ \\
rt & & $(4.142)$ \\
& & $2.652^{* * *}$ \\
ri & $3.177^{* * *}$ & $(8.217)$ \\
& $(7.305)$ & $0.501 * * *$ \\
re & $0.848^{* * *}$ & $(3.434)$ \\
& $(5.490)$ & $0.233^{* * *}$ \\
af & $0.741^{* * *}$ & $(3.334)$ \\
& $(7.549)$ & $0.757^{* * *}$ \\
at & $0.508^{* * *}$ & $(7.890)$ \\
& $(7.406)$ & $3.264^{*}$ \\
rh & $7.130^{* * * *}$ & $(1.858)$ \\
& $(7.238)$ & $-4.1744^{* * *}$ \\
in & $-2.576^{* * *}$ & $(-10.642)$ \\
& $(-9.561)$ & -0.876 \\
c & $2.958^{* * *}$ & $(-1.473)$ \\
$\mathrm{R}^{2}$ & $(5.874)$ & 0.967 \\
F-statistics & 0.995 & $274.893 * * *$ \\
Model & $241.335^{* * *}$ & $(2,2,2,2,2,1,2)$ \\
\hline
\end{tabular}

Note: ${ }^{*} 10 \%$ significance level; ${ }^{* * *} 1 \%$ significance level; T-statistics shown in parentheses.

Table 5 presents the results of the long run effect of sustainable rural tourism on rural community development. The coefficients of sustainable rural tourism were positive and significant at the $1 \%$ level. These results indicated that, with every $1 \%$ increase in sustainable rural tourism, rural community development factors (number of rural community service institutions) increased by $0.049 \%$ (economic benefits of rural tourism) and $0.134 \%$ (number of rural tourists); in other words, the rural community development of China has increased. As a result, it can be concluded that sustainable rural tourism has a positive effect on China's rural community development. This result is consistent with those of Giampiccoli and Kalis [121] and Kavita and Saarinen [122]. Furthermore, this outcome is consistent with China's existing status. Specifically, the income disparity between urban and rural communities is widening as China's overall economy grows at a rapid speed. The government has made significant investments in rural regions in order to address this issue. Simultaneously, the government created programs such as the rural revitalization strategy to aid rural development in all sectors. As a result of the quick execution of a significant number of infrastructure projects, the growth of various rural tourism industries, and the establishment of rural local-characteristic catering and entertainment industries, a huge number of visitors would flock to rural regions for tourism and leisure. This has the potential to raise rural employment and farmer income, therefore reducing the contentious problem of urban-to-rural economic disparity. At the same time, the migration of a significant number of visitors into rural regions will bring with it a slew of difficulties, such as the ecological environment, disagreements between locals and outsiders, and so on. Fortunately, the function of rural communities may handle these accompanying issues. As a result, a great number of rural community service institutions have been formed in China's rural areas. This also demonstrates that sustainable rural tourism actively boosts rural community development.

In addition, the results also suggested that the rural infrastructure construction was positive and significant at the $1 \%$ level. A $1 \%$ improvement in rural infrastructure construction resulted in $3.177 \%$ (economic benefits of rural tourism) and $2.652 \%$ (number of rural tourists) increases in rural community development. This result is consistent with those of Che [123] and Kim and Song [124]. The rural ecological environment positively and significantly affects rural community development. A $1 \%$ improvement in rural ecological environment led to $0.848 \%$ (economic benefits of rural tourism) and $0.501 \%$ (number of 
rural tourists) increases in rural community development. This result is consistent with those of Palmer et al. [125] and Wu [126]. Agricultural fiscal expenditure positively and significantly influences rural community development. A 1\% change in agricultural fiscal expenditure caused $0.741 \%$ (economic benefits of rural tourism) and $0.233 \%$ (number of rural tourists) increases in rural community development. This result is consistent with that of Meng et al. [127]. Agricultural technological progress positively and significantly affects rural community development. A 1\% increase in agricultural technological progress led to about $0.508 \%$ (economic benefits of rural tourism) and $0.757 \%$ (number of rural tourists) increases in rural community development. This result is consistent with that of Bailey and Ngwenyama [128]. Rural human capital also positively and significantly affects rural community development. A 1\% increase in rural human capital led to $7.130 \%$ (economic benefits of rural tourism) and 3.264\% (number of rural tourists) increases in rural community development. This result is consistent with those of Rainey et al. [129] and Nafukho et al. [130]. Industrialization negatively and significantly affects rural community development. A $1 \%$ increase in industrialization led to $-2.576 \%$ (economic benefits of rural tourism) and $-4.174 \%$ (number of rural tourists) decreases in rural community development. This result is consistent with that of Scott and Storper [131].

The above results for long run estimates using the autoregressive distributed lag technique suggest that the predicted variable (rural community development) and explanatory variables (rural infrastructure construction, rural ecological environment, agricultural fiscal expenditure, agricultural technology progress, rural human capital, and industrialization) were in line with the real situation in China. To this end, in the next step, more attention was paid to the short run effect of sustainable rural tourism on rural community development.

\subsection{Short Run Effect of Sustainable Rural Tourism on Rural Community Development}

Based on the results reported in Table 5, this subsection concentrates on the short run effect of sustainable rural tourism on rural community development. To perform the empirical analysis, the maximum lag length was set to 4 . Based on the Akaike information criterion, the selected model for economic benefits of rural tourism was autoregressive distributed lag $(2,1,2,2,2,2,2)$ and the selected model for number of rural tourists was autoregressive distributed lag $(2,2,2,2,2,1,2)$. The results are presented in Table 6.

As the results in Table 6 suggest, the coefficients of sustainable rural tourism were positive and statistically significant at $1 \%$ and $5 \%$ levels. This indicates that, in the short run, rural community development (number of rural community service institutions), with each $1 \%$ increase in economic benefits of rural tourism and number of rural tourists, increased by $0.093 \%$ and $0.138 \%$, respectively. The short run coefficient of sustainable rural tourism was slightly more flexible, relative to the long run estimates. Overall, the positive effect of sustainable rural tourism was more apparent in the short- than in the long run.

Meanwhile, the results in Table 6 also suggest that, in the short run, the rural infrastructure construction, rural ecological environment, agricultural fiscal expenditure, agricultural technology progress, and rural human capital positively and significantly affect rural community development. However, industrialization also had a negative effect on rural community development in the short run. These results in the short run are consistent with those for the long run, even though the coefficients changed in magnitude and statistical significance.

Then, we conducted an analysis of the error correction term. As the results in Table 6 suggest, both coefficients of the error correction term were negative and significant at the $1 \%$ level (for the economic benefits of rural tourism, the coefficient of the error correction term was - 0.777; for the number of rural tourists, the coefficient of the error correction term was -1.119). These findings imply that the short run deviation adjusted to the long run equilibrium at $0.777 \%$ (economic benefits of rural tourism) and $1.119 \%$ (number of rural tourists) in the following year, while rural community development suffered a shock in the current period. 
Table 6. Short run effect results.

\begin{tabular}{ccc}
\hline Variable & cs & cs \\
\hline eb & $0.093^{* * *}$ & \\
& $(5.314)$ & $0.318^{* *}$ \\
rt & & $(2.064)$ \\
& & $2.751^{* * *}$ \\
ri & $2.031^{* * *}$ & $(2.982)$ \\
& $(5.314)$ & 0.301 *** \\
re & $0.075^{* * *}$ & $(4.393)$ \\
& $(5.928)$ & $1.558^{* *}$ \\
af & $0.519^{* * *}$ & $(2.287)$ \\
& $(8.263)$ & $0.514^{* *}$ \\
at & $0.312^{* * *}$ & $(2.046)$ \\
& $(3.305)$ & $10.156^{* * *}$ \\
rh & $6.774^{* * * *}$ & $(3.069)$ \\
& $(4.542)$ & $-1.233^{*}$ \\
in & $-0.769^{* * *}$ & $(-1.947)$ \\
& $(-8.586)$ & $-1.119^{* * *}$ \\
ect-1 & $-0.777^{* * *}$ & $(-2.795)$ \\
& $(4.546)$ & -0.013 \\
c & -0.027 & $(-0.539)$ \\
$\mathrm{R}^{2}$ & $(-0.827)$ & 0.879 \\
F-statistics & 0.862 & $75.405^{* * *}$ \\
Model & $77.903^{* * *}$ & $(2,2,2,2,1,2)$
\end{tabular}

Note: ${ }^{*} 10 \%$ significance level; ${ }^{* *} 5 \%$ significance level; ${ }^{* * *} 1 \%$ significance level; T-statistics shown in parentheses ect, is the error correction term.

\subsection{Diagnostic Test}

Bahmani-Oskooee and Fariditavana [132] and Nkoro and Uko [133] have claimed that an effective estimation of the autoregressive distributed lag bounds test should satisfy some characteristics, such as heteroscedasticity, serial correlation problems, misspecification of the functional form, stability of the parameters, and non-normal errors. The results of the diagnostic tests are shown in Table 7 and Figure 1.

Table 7. Diagnostic test results.

\begin{tabular}{|c|c|c|}
\hline Statistic & F-Statistic & F-Statistic \\
\hline Serial correction ${ }^{1}$ & $\begin{array}{c}2.608 \\
(0.112)\end{array}$ & $\begin{array}{c}2.052 \\
(0.156)\end{array}$ \\
\hline Functional form ${ }^{2}$ & $\begin{array}{c}1.504 \\
(0.155)\end{array}$ & $\begin{array}{c}1.275 \\
(0.165)\end{array}$ \\
\hline Normality $^{3}$ & $\begin{array}{c}0.757 \\
(0.684)\end{array}$ & $\begin{array}{c}2.154 \\
(0.341)\end{array}$ \\
\hline Heteroscedasticity $^{4}$ & $\begin{array}{c}0.947 \\
(0.516)\end{array}$ & 0.852 \\
\hline Cumulative sum ${ }^{5}$ & stable & stable \\
\hline Cumulative sum of squares ${ }^{6}$ & stable & $\begin{array}{c}\text { stable } \\
\text { Sroun 2. Number }\end{array}$ \\
\hline
\end{tabular}

\footnotetext{
${ }^{1}$ lag range multiplier test of residual serial correlation; ${ }^{2}$ Ramsey's RESET test using the square of the fitted values; ${ }^{3}$ based on a test of skewness and kurtosis of residuals; ${ }^{4}$ based on the Breusch-Pagan-Godfrey Test; ${ }^{5}$ stability test by cumulative sum; ${ }^{6}$ stability test by cumulative sum of squares; $p$-values shown in parentheses.
}

By combining the results shown in Table 7 and Figure 1, it is evident that all tests were successfully completed, that is, the estimated autoregressive distributed lag model was effective. Finally, we can conclude that our results were reliable and accurate. 


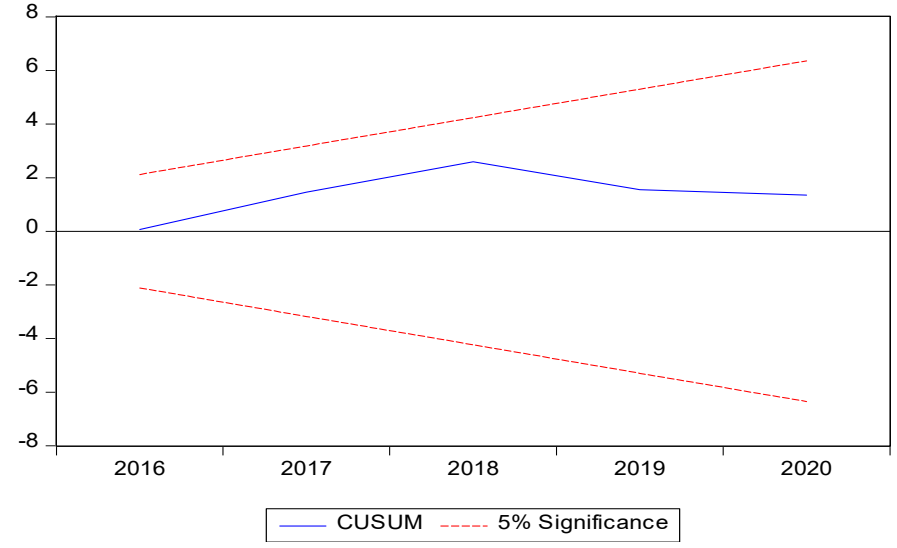

(a)

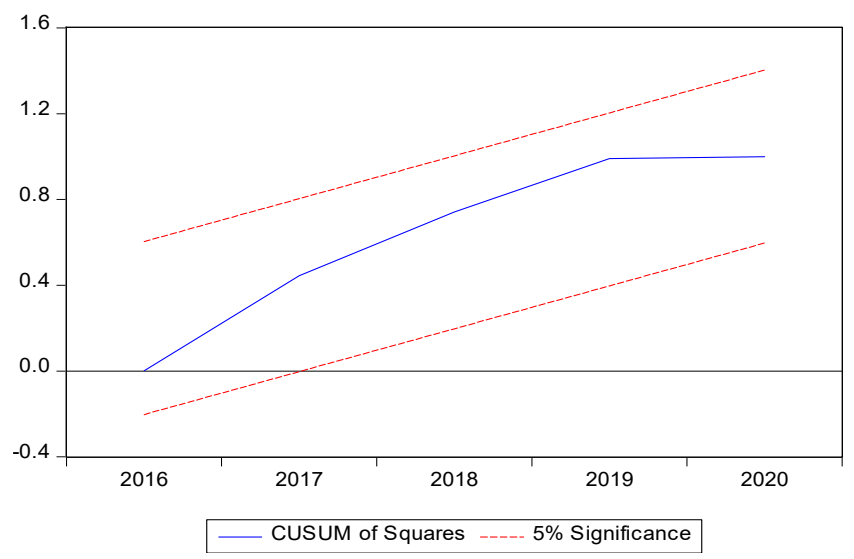

(b)

Group 1: Economic benefits of rural tourism.

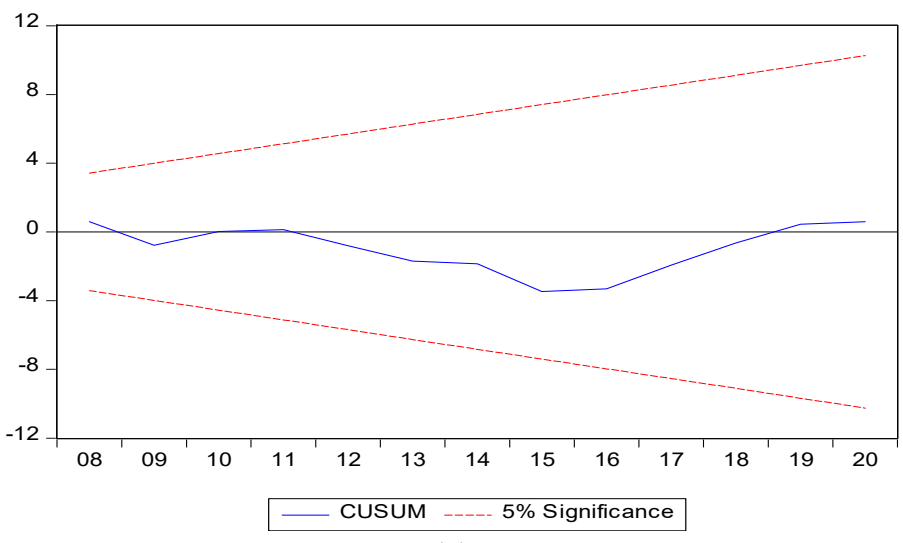

(c)

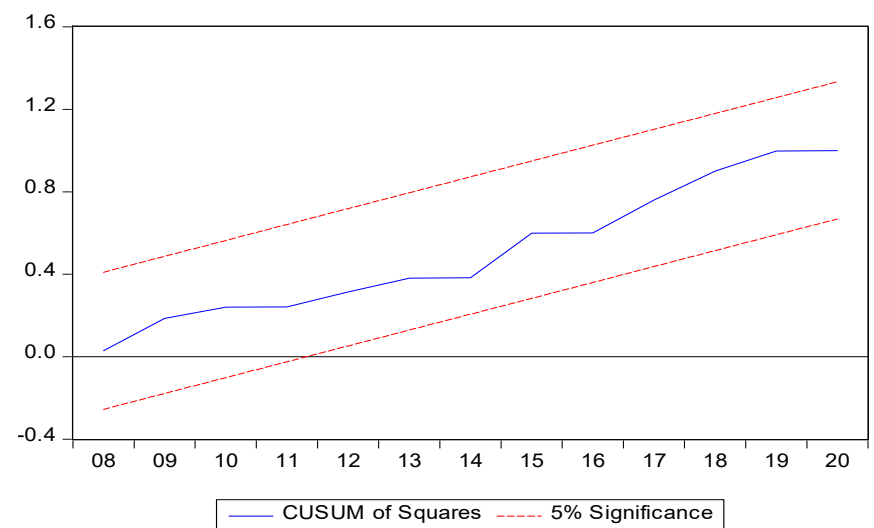

(d)

Group 2: Number of rural tourists.

Figure 1. Diagnostic test results. (a) Plot of cumulative sum of recursive residuals; (b) Plot of cumulative sum of squares of recursive residuals; (c) Plot of cumulative sum of recursive residuals; (d) Plot of cumulative sum of squares of recursive residuals.

\section{Conclusions and Suggestions}

With the rapid growth of China's economy, the income of the population has been increasing. People spend more on leisure and entertainment, not just material needs. For this reason, China's rural tourism has developed vigorously. Meanwhile, in this wave of rapid rural tourism development, China's rural community development has also developed rapidly. Beeton [134] has claimed that rural tourism is a noteworthy driver of community development. Therefore, with this background, we took China as an example to explore how sustainable rural tourism affects rural community development in the long- and short run over the period 1994-2020. Based on previous studies, sustainable rural tourism was measured using two indicators: Economic benefits of rural tourism and number of rural tourists. Rural community development was measured through the number of community service institutions. Meanwhile, some other key variables were also used to realize this basic aim. Using the autoregressive distributed lag bounds technique to conduct the empirical analyses, the key results suggest that sustainable rural tourism positively and significantly affects rural community development. Considering the results of this paper, it can be found that sustainable rural tourism is making a positive contribution to China's rural community development, whether in the long or short run.

This paper contributes to the literature in four aspects: First, China is the largest developing country in the world. Using it as a research sample is more representative than other developing countries. Second, according to our current knowledge, this paper comprises the first time that the effect of sustainable rural tourism on rural community 
development has been studied from an empirical perspective. Third, two indicators were used to measure sustainable rural tourism (one was the total amount of rural tourism revenue, while the other was the number of rural tourists). Meanwhile, the empirical results of both indicators can be regarded as a robustness test with respect to the accuracy and reliability of our results. Fourth, a series of econometric techniques were used to keep our empirical results more accurate.

This paper contributes to the literature regarding the effect of sustainable rural tourism on rural community development, and expands upon it by explaining the contribution of the effect of sustainable rural tourism on rural community development. With the increasing importance of China's rural community development and the rapid development of rural tourism, the findings of this paper may serve as a reference for China's local government to issue some appropriate policies to balance the sustainable development of rural tourism and rural community development. As a result, there are some suggestions for China's local policy-makers, as follows: (1) As our empirical findings indicate, whether in the long or short run, sustainable rural tourism always plays a positive role in promoting the rural community development; that is, at this stage, local governments should try their best to attract more tourists to travel to their rural areas. This can be helpful for rural community development. (2) Local governments can also promote rural community development by increasing the rural infrastructure construction, rural ecological environment protection, agricultural financial expenditure, and updating of the agricultural technology.

Finally, it is extremely vital to emphasize the limitations and future research directions in this paper, which may help in future perspectives: (1) This paper only used timeseries data, taking regional differences into consideration; however, China is the largest developing country, with a vast territory. Future studies may use panel data that include the 31 provinces in order to re-examine the effect of sustainable rural tourism on rural community development. New and interesting results may be generated. (2) In addition, this paper only concentrates on one country (China). Due to the fact that China differs from other countries, future studies should take other countries into account in order to perform a comparative study, which may produce more new findings. (3) This paper uses secondary data to conduct an empirical analysis. Future studies may use primary data to fulfil further empirical analyses. (4) Future studies may also take other variables into consideration, which may affect the effect of sustainable rural tourism on rural community development. (5) In this paper, we only used the number of rural community service institutions to reflect rural community development. To produce more reliable results, future research may use further indicators, such as rural community participation, for the measurement of rural community development. (6) Because of the COVID-19 outbreak, rural tourism in China has remained stagnant since 2020. It will also have an influence on rural community development. As a result, future research could be added to the COVID-19 pandemic variables, and the impact of rural tourism on rural community development could be reconsidered. This might result in a more intriguing outcome.

Author Contributions: Conceptualization, Y.H. and B.-R.C.; Data curation, X.G., R.W. and Y.W.; Formal analysis, R.W.; Investigation, X.G., R.W., Y.W. and B.-R.C.; Methodology, Y.H. and Y.W.; Project administration, B.-R.C.; Resources, B.-R.C.; Software, Y.H.; Validation, R.W.; Visualization, B.-R.C.; Writing—original draft, Y.H.; Writing—review \& editing, X.G. and Y.W. All authors have read and agreed to the published version of the manuscript.

Funding: This research received no external funding.

Institutional Review Board Statement: Not applicable.

Informed Consent Statement: Not applicable.

Data Availability Statement: The data presented in this paper are available from the National.Bureau of Statistics (https:/ / data.stats.gov.cn/ (accessed on 1 November 2021)) and Statistics of Yearbook.

Conflicts of Interest: The authors declare no conflict of interest. 


\section{References}

1. Tao, L.I.U.; Fuying, X. Research on the Driving Force of the Sustainable Development of Rural Tourism in the New Rural Construction. J. Anhui Agric. Sci. 2010, 38, 2102-2104.

2. Palacios-Florencio, B.; Santos-Roldán, L.; Berbel-Pineda, J.M.; Castillo-Canalejo, A.M. Sustainable Tourism as a Driving Force of the Tourism Industry in a Post-COVID-19 Scenario. Soc. Indic. Res. 2021, 158, 1-21. [CrossRef]

3. Gao, J.; Wu, B. Revitalizing Traditional Villages through Rural Tourism: A Case Study of Yuanjia Village, Shaanxi Province, China. Tour. Manag. 2017, 63, 223-233. [CrossRef]

4. Yun, Y.E. On Public Space of New Rural Community. J. Henan Univ. Urban Constr. 2012, 5, 17-20.

5. Xiao-hua, C. Review of Geography of the Rural Community in China. J. Anhui Agric. Sci. 2005, 4, 559-561.

6. Lei, L.I. The Problems Existing in the Construction of Rural Community in Jilin Province and Corresponding Countermeasures. J. Anhui Agric. Sci. 2011, 28, 17611-17612.

7. Zhao, X.; Li, J.; Bai, Y. On Cultural Activities of Rural Community in Shanxi Province. J. Shanxi Agric. Univ. Soc. Sci. Ed. 2012, 3.

8. Su-wen, F. The Research on Strategies of Education in Rural Communities. Adult Educ. 2012, 9, $282-286$.

9. Yan-qi, S. The Carrier of Ecological and Environmental Protection of Self-Organization of China's Rural Community. China Popul. Resour. Environ. 2010, 1, 81-86.

10. Guo, W.; Huang, Z.F. Study on the Development of Community Power and Functions under the Background of the Development of Rural Tourism-Based on the Investigation of Two Typical Cases in Daizu Garden and Yubeng Community, Yunnan Province. Tour. Trib. 2011, 26, 83-92.

11. Jing-Ming, H.E. A Study on Rural Tourism Overseas. Tour. Trib. 2003, 1, 76-80.

12. Du, Z.B.; Su, Q. Study on the Relationship between the Community Participation of Rural Tourism, Residents' Perceived Tourism Impact and Sense of Community Involvement-A Case Study of Anji Rural Tourism Destination, Zhejiang Province. Tour. Trib. 2011, 26, 65-70.

13. Du, Z.; Su, Q. Influence of Sense of Community on Community Involvement in Rural Tourism Destination: A Case Study of Anji County in Zhejiang Province. Tour. Sci. 2013, 27, 61-71.

14. Shaohua, S. Power Structure, Operation Strategies of Community Participation in Rural Tourism and Their Impact Studies: Based on Scenic Spot Merger Events of BS Village in the Suburbs of Beijing. J. Beijing Int. Stud. Univ. 2012, 11, 73-83.

15. Guo, H.; Han, F. Review on the Development of Rural Tourism in China. Prog. Geogr. 2010, 12, 1597-1605.

16. Yishan, X.U. On Humane Sustainable Rural Tourism and Development. J. Wuyi Univ. 2010, 1, 48-51.

17. Wang, F.; Hao, X. Evaluation of Community Participation in Rural Tourism Areas Based on Analytic Hierarchy Process-Taking Diaowo Village, Pinggu District, Beijing as an Example. Tour. Trib. 2008, 23, 52-57.

18. Jie, Z.O.U. Research on The Development Model of Rural Tourism Community-The Case of Rizhao Rural Tourism. Territ. Nat. Resour. Study 2015, 5, 78-81.

19. Qiao-hui, M.A. On Community-Establishment-Oriented Rural Tourism Development. J. Sichuan High. Inst. Cuis. 2011, 6, 47-49.

20. Fong, S.F.; Lo, M.C. Community Involvement and Sustainable Rural Tourism Development: Perspectives from the Local Communities. Eur. J. Tour. Res. 2015, 11, 125-146.

21. Fun, F.S.; Chiun, L.M.; Songan, P.; Nair, V. The Impact of Local Communities' Involvement and Relationship Quality on Sustainable Rural Tourism in Rural Area, Sarawak. The Moderating Impact of Self-Efficacy. Procedia-Soc. Behav. Sci. 2014, 144, 60-65. [CrossRef]

22. Fong, S.-F.; Lo, M.-C.; Songan, P.; Nair, V. Self-Efficacy and Sustainable Rural Tourism Development: Local Communities' Perspectives from Kuching, Sarawak. Asia Pac. J. Tour. Res. 2017, 22, 147-159. [CrossRef]

23. Aref, F.; Gill, S.S. Rural Tourism Development through Rural Cooperatives. Nat. Sci. 2009, 7, 68-73.

24. Ribeiro, M.; Marques, C. Rural Tourism and the Development of Less Favoured Areas-Between Rhetoric and Practice. Int. J. Tour. Res. 2002, 4, 211-220. [CrossRef]

25. De Jesus, P.L. Gaining Community Support for Tourism in Rural Areas in Portugal 1. In Proceedings of the Communities as a Part of Sustainable Rural Tourism-Success Factor or Inevitable Burden, Kotka, Finland, 10-11 September 2013 ; p. 28.

26. Lo, M.-C.; Mohamad, A.A.; Songan, P.; Yeo, A.W. Positioning Rural Tourism: Perspectives from the Local Communities. Int. J. Trade Econ. Finance 2012, 3, 59-65. [CrossRef]

27. Gannon, A. Rural Tourism as a Factor in Rural Community Economic Development for Economies in Transition. J. Sustain. Tour. 1994, 2, 51-60. [CrossRef]

28. Hwang, D.; Stewart, W.P.; Ko, D. Community Behavior and Sustainable Rural Tourism Development. J. Travel Res. 2012, 51, 328-341. [CrossRef]

29. Hambira, W.L.; Saarinen, J.; Atlhopheng, J.R.; Manwa, H. Climate Change, Tourism, and Community Development: Perceptions of Maun Residents, Botswana. Tour. Rev. Int. 2021, 25, 105-117. [CrossRef]

30. Idziak, W.; Majewski, J.; Zmyślony, P. Community Participation in Sustainable Rural Tourism Experience Creation: A Long-Term Appraisal and Lessons from a Thematic Villages Project in Poland. J. Sustain. Tour. 2015, 23, 1341-1362. [CrossRef]

31. Amir, A.F.; Abd Ghapar, A.; Jamal, S.A.; Ahmad, K.N. Sustainable Tourism Development: A Study on Community Resilience for Rural Tourism in Malaysia. Procedia-Soc. Behav. Sci. 2015, 168, 116-122. [CrossRef]

32. Dogra, R.; Gupta, A. Barriers to Community Participation in Tourism Development: Empirical Evidence from a Rural Destination. South Asian J. Tour. Herit. 2012, 5, 129-142. 
33. Mair, H.; Reid, D.G.; George, W. Chapter 10. Globalisation, Rural Tourism and Community Power. In Rural Tourism and Sustainable Business; Hall, D., Kirkpatrick, I., Mitchell, M., Eds.; Channel View Publications: Bristol, UK, 2005; Volume 26, pp. 165-179.

34. Huang, Y.-H.; Stewart, W.P. Rural Tourism Development: Shifting Basis of Community Solidarity. J. Travel Res. 1996, 34, 26-31. [CrossRef]

35. Wijijayanti, T.; Agustina, Y.; Winarno, A.; Istanti, L.N.; Dharma, B.A. Rural Tourism: A Local Economic Development. Australas. Account. Bus. Finance J. 2020, 14, 5-13. [CrossRef]

36. Petrzelka, P.; Krannich, R.S.; Brehm, J.; Trentelman, C.K. Rural Tourism and Gendered Nuances. Ann. Tour. Res. 2005, 32, 1121-1137. [CrossRef]

37. Manaf, A.; Purbasari, N.; Damayanti, M.; Aprilia, N.; Astuti, W. Community-Based Rural Tourism in Inter-Organizational Collaboration: How Does It Work Sustainably? Lessons Learned from Nglanggeran Tourism Village, Gunungkidul Regency, Yogyakarta, Indonesia. Sustainability 2018, 10, 2142. [CrossRef]

38. Lenaoa, M.; Saarinen, J. Integrated Rural Tourism as a Tool for Community Tourism Development: Exploring Culture and Heritage Projects in the North-East District of Botswana. S. Afr. Geogr. J. Suid-Afr. Geogr. Tydskr. 2015, 97, 203-216. [CrossRef]

39. Falak, S.; Chiun, L.M.; Wee, A.Y. Sustainable Rural Tourism: An Indigenous Community Perspective on Positioning Rural Tourism. Tour. Int. Interdiscip. J. 2016, 64, 311-327.

40. Verbole, A. Actors, Discourses and Interfaces of Rural Tourism Development at the Local Community Level in Slovenia: Social and Political Dimensions of the Rural Tourism Development Process. J. Sustain. Tour. 2000, 8, 479-490. [CrossRef]

41. Ertuna, B.; Kirbas, G. Local Community Involvement in Rural Tourism Development: The Case of Kastamonu, Turkey. PASOS Rev. Tur. Patrim. Cult. 2012, 10, 17-24. [CrossRef]

42. Yahya, A.; Fang, J.T.Y. Local Community Attitudes Toward Sustainable Rural Tourism Case Study of Nusatourism Village in Aceh. PEOPLE Int. J. Soc. Sci. 2019, 4, 1026-1038. [CrossRef]

43. Herawati, A.; Purwaningsih, A.; Pudianti, A.; Surya, R.V. Rural Tourism Community Empowerment Based on Local Resources for Improving Community Welfare: Case on Pentingsari Village, Yogyakarta, Indonesia. Rev. Integr. Bus. Econ. Res. 2014, 3, 88-101.

44. Ezeuduji, I.O.; Rid, W. Rural Tourism Offer and Local Community Participation in The Gambia. Tourismos 2011, 6, $187-211$.

45. Zou, T.; Huang, S.; Ding, P. Toward a Community-Driven Development Model of Rural Tourism: The Chinese Experience. Int. J. Tour. Res. 2014, 16, 261-271. [CrossRef]

46. Xu, K.; Zhang, J.; Tian, F. Community Leadership in Rural Tourism Development: A Tale of Two Ancient Chinese Villages. Sustainability 2017, 9, 2344. [CrossRef]

47. Tongqian, Z.; Yanhua, W.; Rifang, C. On the Community-Based Development Model of Rural Tourism-A Case Study of Da Ying Village, Tong Zhou District, Beijing. J. Beijing Int. Stud. Univ. 2007, 1, 53-59.

48. Hai-peng, C. Study on the Rural Tourism Development under the Perspective of New Rural Construction. J. Anhui Agric. Sci. 2009, 27, 13333-13335.

49. Weng, S.; Peng, H. The Impact of Power Relationship on Community Participation in Tourism Development: A Case from Furong Village at Nanxi River Basin, Zhejiang Province. Tour. Trib. 2010, 25, 51-57.

50. Zhang, S.; Sun, Z.; Ma, W.; Valentinov, V. The Effect of Cooperative Membership on Agricultural Technology Adoption in Sichuan, China. China Econ. Rev. 2020, 62, 101334. [CrossRef]

51. Wang, M.; Jiang, J.; Xu, S.; Guo, Y. Community Participation and Residents' Support for Tourism Development in Ancient Villages: The Mediating Role of Perceptions of Conflicts in the Tourism Community. Sustainability 2021, 13, 2455. [CrossRef]

52. Yan, Y.; Jiang, S.; Wang, Z. Rural Community Participation Tourism to Promote Construction of the New Rural. J. Ningbo Polytech. 2007, 3, 11-14.

53. Lin, S.; Yang, G.; Wei, Y.; Lai, Q. An Empirical Study on Rural Residents' Welfare Perception in Rural Tourism CommunitiesCases on Five Rural Tourism Communities Arround Ningde World Geopark. J. Fujian Agric. For. Univ. Philos. Soc. Sci. 2017, 3 , 86-93.

54. Xian-feng, L.I.; Jian, H. A Case Study on Gucheng Village, Ningxia: Influence of Rural Tourism on Hui Community. Resour. Ind. 2010, 11, 27-32.

55. Zhou, Y.; Jiang, J.; Wang, X. A Study of Community-Driven Endogenous Rural Tourism Development Model. Tour. Sci. 2009, 4, 36-41.

56. Dai Zeguang, H.M. The Analysis of Stakeholders in the Rural Tourism of Community Participation Based on the Dynamic Game. Econ. Manag. 2009, 11, 27-32.

57. Ping, Y.U. Analysis of Sustainable Development of Rural Tourism Based on Community Empowerment. J. Harbin Univ. Commer. Soc. Sci. Ed. 2010, 2, 1-23.

58. Liao, Z.; Zhang, L. A Study on the Present Situation and Elements Related to the Community Participation Model of Rural Tourism. Theory Res. 2009, 32, 102-103.

59. Bao, J.; Sun, J. On the Community Participation in Tourism Planning. Planners 2003, 7, 32-38.

60. Ying, T.; Zhou, Y. Community, Governments and External Capitals in China's Rural Cultural Tourism: A Comparative Study of Two Adjacent Villages. Tour. Manag. 2007, 28, 96-107. [CrossRef]

61. Bao, J.; Sun, J. Community Participation in Tourism of Yubeng Village: Means of Participation and Its Significance for Empowerment. Proc. Tour. Forum 2008, 4, 58-65. 
62. Ivars-Baidal, J.A.; Vera-Rebollo, J.F.; Perles-Ribes, J.; Femenia-Serra, F.; Celdrán-Bernabeu, M.A. Sustainable Tourism Indicators: What's New within the Smart City/Destination Approach? J. Sustain. Tour. 2021, 1-24. [CrossRef]

63. Lee, T.H.; Jan, F.-H.; Liu, J.-T. Developing an Indicator Framework for Assessing Sustainable Tourism: Evidence from a Taiwan Ecological Resort. Ecol. Indic. 2021, 125, 107596. [CrossRef]

64. Fons, M.V.S.; Fierro, J.A.M.; y Patiño, M.G. Rural Tourism: A Sustainable Alternative. Appl. Energy 2011, 88, 551-557. [CrossRef]

65. McAreavey, R.; McDonagh, J. Sustainable Rural Tourism: Lessons for Rural Development. Sociol. Rural. 2011, 51, 175-194. [CrossRef]

66. Ghaderi, Z.; Henderson, J.C. Sustainable Rural Tourism in Iran: A Perspective from Hawraman Village. Tour. Manag. Perspect. 2012, 2, 47-54. [CrossRef]

67. Muresan, I.C.; Oroian, C.F.; Harun, R.; Arion, F.H.; Porutiu, A.; Chiciudean, G.O.; Todea, A.; Lile, R. Local Residents' Attitude Toward Sustainable Rural Tourism Development. Sustainability 2016, 8, 100. [CrossRef]

68. Park, J.; Lee, S. Smart Village Projects in Korea: Rural Tourism, 6th Industrialization, and Smart Farming. In Smart Villages in the EU and Beyond; Visvizi, A., Lytras, M.D., Mudri, G., Eds.; Emerald Publishing Limited: Bingley, UK, 2019.

69. Rahman, M.K.; Masud, M.M.; Akhtar, R.; Hossain, M.M. Impact of Community Participation on Sustainable Development of Marine Protected Areas: Assessment of Ecotourism Development. Int. J. Tour. Res. 2021, 23, 1-11. [CrossRef]

70. Roba Gamo, B.; Woldeamanuel Habebo, T.; Tsegaye Mekonnen, G.; Park, D.-B. Determinants of Community Participation in a Watershed Development Program in Southern Ethiopia. Community Dev. 2021, 52, 1-17. [CrossRef]

71. Dova, E.; Sivitanidou, A.; Anastasi, N.R.; Tzortzi, J.G.-N. A Mega-Event in a Small City: Community Participation, Heritage and Scale in the Case of Pafos 2017 European Capital of Culture. Eur. Plan. Stud. 2021, 5, 1-21. [CrossRef]

72. Ko, G.; Routray, J.K.; Ahmad, M.M. ICT Infrastructure for Rural Community Sustainability. Community Dev. 2019, 50, 51-72. [CrossRef]

73. Sharp, J.S.; Agnitsch, K.; Ryan, V.; Flora, J. Social Infrastructure and Community Economic Development Strategies: The Case of Self-Development and Industrial Recruitment in Rural Iowa. J. Rural Stud. 2002, 18, 405-417. [CrossRef]

74. Li, L.W.; Liu, J.; Zhang, Z.; Xu, H. Late-Life Depression in Rural China: Do Village Infrastructure and Availability of Community Resources Matter? Int. J. Geriatr. Psychiatry 2015, 30, 729-736. [CrossRef] [PubMed]

75. Liu, J.; Li, C.; Tao, J.; Ma, Y.; Wen, X. Spatiotemporal Coupling Factors and Mode of Tourism Industry, Urbanization and Ecological Environment: A Case Study of Shaanxi, China. Sustainability 2019, 11, 4923. [CrossRef]

76. Xie, X.; Sun, H.; Gao, J.; Chen, F.; Zhou, C. Spatiotemporal Differentiation of Coupling and Coordination Relationship of Tourism-Urbanization-Ecological Environment System in China's Major Tourist Cities. Sustainability 2021, 13, 5867. [CrossRef]

77. Zhang, T.; Li, L. Research on Temporal and Spatial Variations in the Degree of Coupling Coordination of Tourism-UrbanizationEcological Environment: A Case Study of Heilongjiang, China. Environ. Dev. Sustain. 2021, 23, 8474-8491. [CrossRef]

78. Zeng, G.; Zhang, C.; Li, S.; Sun, H. The Dynamic Impact of Agricultural Fiscal Expenditures and Gross Agricultural Output on Poverty Reduction: A VAR Model Analysis. Sustainability 2021, 13, 5766. [CrossRef]

79. Chen, X.; Zhang, X.; Song, Y.; Liang, X.; Wang, L.; Geng, Y. Fiscal Decentralization, Urban-Rural Income Gap, and Tourism. Sustainability 2020, 12, 10398. [CrossRef]

80. Zeng, S.; Gao, L.; Shen, R.; Ma, Y.; Li, H. Fiscal Decentralization, Pollution and China's Tourism Revenue. Sustainability 2020, $12,1925$. [CrossRef]

81. He, Y.; Liang, C.; Liu, Y. Spatio-Temporal Evolution and Regional Difference Analysis of China's Agricultural Technology Progress Under Two-Way Output. In Proceedings of the International Conference on Management Science and Engineering Management, Chisinau, Moldova, 30 July-2 August 2020; pp. 81-92.

82. Liu, Y.; Ji, D.; Zhang, L.; An, J.; Sun, W. Rural Financial Development Impacts on Agricultural Technology Innovation: Evidence from China. Int. J. Environ. Res. Public Health 2021, 18, 1110. [CrossRef]

83. Xu, X.; Zhang, N.; Zhao, D.; Liu, C. The Effect of Trade Openness on the Relationship between Agricultural Technology Inputs and Carbon Emissions: Evidence from a Panel Threshold Model. Environ. Sci. Pollut. Res. 2021, 28, 9991-10004. [CrossRef]

84. Razzaq, A.R.A.; Mohamad, N.H.; Kader, S.S.S.A.; Mustafad, M.Z. Developing Human Capital for Rural Community Tourism: Using Experiential Learning Approach. Procedia-Soc. Behav. Sci. 2013, 93, 1835-1839. [CrossRef]

85. Su, Z.; Aaron, J.R.; Guan, Y.; Wang, H. Sustainable Livelihood Capital and Strategy in Rural Tourism Households: A Seasonality Perspective. Sustainability 2019, 11, 4833. [CrossRef]

86. Kimbu, A.N.; Ngoasong, M.Z.; Adeola, O.; Afenyo-Agbe, E. Collaborative Networks for Sustainable Human Capital Management in Women's Tourism Entrepreneurship: The Role of Tourism Policy. Tour. Plan. Dev. 2019, 16, 161-178. [CrossRef]

87. Long, H.; Zou, J.; Liu, Y. Differentiation of Rural Development Driven by Industrialization and Urbanization in Eastern Coastal China. Habitat Int. 2009, 33, 454-462. [CrossRef]

88. Jiang, G.; He, X.; Qu, Y.; Zhang, R.; Meng, Y. Functional Evolution of Rural Housing Land: A Comparative Analysis across Four Typical Areas Representing Different Stages of Industrialization in China. Land Use Policy 2016, 57, 645-654. [CrossRef]

89. Dangi, T.B.; Petrick, J.F. Augmenting the Role of Tourism Governance in Addressing Destination Justice, Ethics, and Equity for Sustainable Community-Based Tourism. Tour. Hosp. 2021, 2, 15-42. [CrossRef]

90. Pesaran, M.H.; Shin, Y.; Smith, R.J. Bounds Testing Approaches to the Analysis of Level Relationships. J. Appl. Econom. 2001, 16, 289-326. [CrossRef] 
91. Osinubi, T.T.; Osinubi, O.B.; Tabash, M.I.; Ajayi, A.O.; Tran, D.K. The Impact of Corruption on Tourism Sector in Nigeria: Empirical Insights by Using an Autoregressive Distributed Lag Bounds (ARDL) Testing Approach. Int. J. Hosp. Tour. Adm. 2021, 22, 1-20. [CrossRef]

92. El Menyari, Y. Effect of Tourism FDI and International Tourism to the Economic Growth in Morocco: Evidence from ARDL Bound Testing Approach. J. Policy Res. Tour. Leis. Events 2021, 13, 222-242. [CrossRef]

93. Razzaq, A.; Sharif, A.; Najmi, A.; Tseng, M.-L.; Lim, M.K. Dynamic and Causality Interrelationships from Municipal Solid Waste Recycling to Economic Growth, Carbon Emissions and Energy Efficiency Using a Novel Bootstrapping Autoregressive Distributed Lag. Resour. Conserv. Recycl. 2021, 166, 105372. [CrossRef]

94. Chi, J. Is There Complementarity or Substitutability among Hawaiian Islands? Evidence from the Autoregressive Distributed Lag Approach. Curr. Issues Tour. 2021, 24, 2013-2027. [CrossRef]

95. Rehman, A.; Ma, H.; Irfan, M.; Ahmad, M.; Traore, O. Investigating the Influence of International Tourism in Pakistan and Its Linkage to Economic Growth: Evidence from ARDL Approach. SAGE Open 2020, 10, 2158244020932525. [CrossRef]

96. Udemba, E.N.; Yalçıntaş, S. Interacting Force of Foreign Direct Invest (FDI), Natural Resource and Economic Growth in Determining Environmental Performance: A Nonlinear Autoregressive Distributed Lag (NARDL) Approach. Resour. Policy 2021, 73, 102168. [CrossRef]

97. Frimpong Magnus, J.; Oteng-Abayie, E.F. Bounds Testing Approach: An Examination of Foreign Direct Investment, Trade, and Growth Relationships. Am. J. Appl. Sci. Forthcom. 2006, 7, 2079-2085.

98. Bist, J.P.; Bista, N.B. Finance-Growth Nexus in Nepal: An Application of the ARDL Approach in the Presence of Structural Breaks. Vikalpa 2018, 43, 236-249. [CrossRef]

99. Amusa, H.; Amusa, K.; Mabugu, R. Aggregate Demand for Electricity in South Africa: An Analysis Using the Bounds Testing Approach to Cointegration. Energy Policy 2009, 37, 4167-4175. [CrossRef]

100. Adom, P.K.; Bekoe, W.; Akoena, S.K.K. Modelling Aggregate Domestic Electricity Demand in Ghana: An Autoregressive Distributed Lag Bounds Cointegration Approach. Energy Policy 2012, 42, 530-537. [CrossRef]

101. Dergiades, T.; Tsoulfidis, L. Revisiting Residential Demand for Electricity in Greece: New Evidence from the ARDL Approach to Cointegration Analysis. Empir. Econ. 2011, 41, 511-531. [CrossRef]

102. Kumar, R.R.; Stauvermann, P.J.; Loganathan, N.; Kumar, R.D. Exploring the Role of Energy, Trade and Financial Development in Explaining Economic Growth in South Africa: A Revisit. Renew. Sustain. Energy Rev. 2015, 52, 1300-1311. [CrossRef]

103. Sari, R.; Ewing, B.T.; Soytas, U. The Relationship between Disaggregate Energy Consumption and Industrial Production in the United States: An ARDL Approach. Energy Econ. 2008, 30, 2302-2313. [CrossRef]

104. Moh'd Hemed, I.; Faki, S.M.; Suleiman, S.H. Economic Growth and Environmental Pollution in Brunei: ARDL Bounds Testing Approach to Cointegration: A New Perspective. Emerg. Issues Dev. Econ. Trade. 2019, 10, 1-11.

105. Pan, L.; Mishra, V. Stock Market Development and Economic Growth: Empirical Evidence from China. Econ. Model. 2018, 68, 661-673. [CrossRef]

106. Shin, Y.; Yu, B.; Greenwood-Nimmo, M. Modelling Asymmetric Cointegration and Dynamic Multipliers in a Nonlinear ARDL Framework. In Festschrift in Honor of Peter Schmidt; Sickles, R.C., Horrace, W.C., Eds.; Springer: New York, USA, $2014 ;$ pp. $281-314$.

107. Altinay, G.; Karagol, E. Structural Break, Unit Root, and the Causality between Energy Consumption and GDP in Turkey. Energy Econ. 2004, 26, 985-994. [CrossRef]

108. Lise, W.; Van Montfort, K. Energy Consumption and GDP in Turkey: Is There a Co-Integration Relationship? Energy Econ. 2007, 29, 1166-1178. [CrossRef]

109. Stern, D.I. A Multivariate Cointegration Analysis of the Role of Energy in the US Macroeconomy. Energy Econ. 2000, 22, 267-283. [CrossRef]

110. Lai, C.S.; Tao, Y.; Xu, F.; Ng, W.W.; Jia, Y.; Yuan, H.; Huang, C.; Lai, L.L.; Xu, Z.; Locatelli, G. A Robust Correlation Analysis Framework for Imbalanced and Dichotomous Data with Uncertainty. Inf. Sci. 2019, 470, 58-77. [CrossRef]

111. Nikolić, D.; Mureşan, R.C.; Feng, W.; Singer, W. Scaled Correlation Analysis: A Better Way to Compute a Cross-Correlogram. Eur. J. Neurosci. 2012, 35, 742-762. [CrossRef]

112. DeJong, D.N.; Nankervis, J.C.; Savin, N.E.; Whiteman, C.H. The Power Problems of Unit Root Test in Time Series with Autoregressive Errors. J. Econom. 1992, 53, 323-343. [CrossRef]

113. Pantula, S.G.; Gonzalez-Farias, G.; Fuller, W.A. A Comparison of Unit-Root Test Criteria. J. Bus. Econ. Stat. 1994, 12, 449-459.

114. Phillips, P.C. Time Series Regression with a Unit Root. Econom. J. Econom. Soc. 1987, 277-301. [CrossRef]

115. Lanne, M.; Lütkepohl, H.; Saikkonen, P. Comparison of Unit Root Tests for Time Series with Level Shifts. J. Time Ser. Anal. 2002, 23, 667-685. [CrossRef]

116. Hall, A. Testing for a Unit Root in Time Series with Pretest Data-Based Model Selection. J. Bus. Econ. Stat. 1994, 12, 461-470.

117. Lanne, M.; Lütkepohl, H. Unit Root Tests for Time Series with Level Shifts: A Comparison of Different Proposals. Econ. Lett. 2002, 75, 109-114. [CrossRef]

118. Lau, C.K.M. A More Powerful Panel Unit Root Test with an Application to PPP. Appl. Econ. Lett. 2009, 16, 75-80. [CrossRef]

119. Hassler, U.; Wolters, J. On the Power of Unit Root Tests against Fractional Alternatives. Econ. Lett. 1994, 45, 1-5. [CrossRef]

120. Sam, C.Y.; McNown, R.; Goh, S.K. An Augmented Autoregressive Distributed Lag Bounds Test for Cointegration. Econ. Model. 2019, 80, 130-141. [CrossRef] 
121. Giampiccoli, A.; Kalis, J.H. Tourism, Food, and Culture: Community-Based Tourism, Local Food, and Community Development in M Pondoland. Cult. Agric. Food Environ. 2012, 34, 101-123. [CrossRef]

122. Kavita, E.; Saarinen, J. Tourism and Rural Community Development in Namibia: Policy Issues Review. Fenn. Int. J. Geogr. 2016, 194, 79-88. [CrossRef]

123. Che, C.F. Re-Inventing Community Development: Utilizing Relational Networking and Cultural Assets for Infrastructure Provision. Societies 2018, 8, 84. [CrossRef]

124. Kim, D.; Song, S.-K. The Multifunctional Benefits of Green Infrastructure in Community Development: An Analytical Review Based on 447 Cases. Sustainability 2019, 11, 3917. [CrossRef]

125. Palmer, M.A.; Ambrose, R.F.; Poff, N.L. Ecological Theory and Community Restoration Ecology. Restor. Ecol. 1997, 5, 291-300. [CrossRef]

126. Wu, V.C.-S. The Geography and Disparities of Community Philanthropy: A Community Assessment Model of Needs, Resources, and Ecological Environment. Volunt. Int. J. Volunt. Nonprofit Organ. 2021, 32, 351-371. [CrossRef]

127. Meng, Z.; Meng, H.; Wang, G. Analysis of the Economic Effect of Fiscal Expenditure on Agriculture Based on New Rural Community Construction. J. Shanxi Agric. Sci. 2012, 06, 682-685.

128. Bailey, A.; Ngwenyama, O. Bridging the Generation Gap in ICT Use: Interrogating Identity, Technology and Interactions in Community Telecenters. Inf. Technol. Dev. 2010, 16, 62-82. [CrossRef]

129. Rainey, D.V.; Robinson, K.L.; Allen, I.; Christy, R.D. Essential Forms of Capital for Sustainable Community Development. Am. J. Agric. Econ. 2003, 85, 708-715. [CrossRef]

130. Nafukho, F.M.; Hairston, N.; Brooks, K. Human Capital Theory: Implications for Human Resource Development. Hum. Resour. Dev. Int. 2004, 7, 545-551. [CrossRef]

131. Scott, A.J.; Storper, M. Industrialization and Regional Development. In Pathways to Industrialization and Regional Development; Storper, M., Scott, A.J., Eds.; Routledge: London, UK, 2005; pp. 15-28.

132. Bahmani-Oskooee, M.; Fariditavana, H. Nonlinear ARDL Approach, Asymmetric Effects and the J-Curve. J. Econ. Stud. 2015, 42, 519-530. [CrossRef]

133. Nkoro, E.; Uko, A.K. Autoregressive Distributed Lag (ARDL) Cointegration Technique: Application and Interpretation. J. Stat. Econom. Methods 2016, 5, 63-91.

134. Beeton, S. Community Development through Tourism; Landlinks Press: Collingwood, Australia, 2006. 